observation of December 3, the relative humidity of the air was 75 per cent., the wind calm, and the barometer, corrected to $32^{\circ}$ and sea-level, $30 \cdot 284$ inches. On January 7 , relative humidity was $76^{\circ} 5$ per cent., wind faint ; barometer $30^{\circ} 499$ inches. The altitude of this station is 480 feet; lat. $54^{\circ} \mathrm{N}$., long. $\mathrm{I}^{\circ} \cdot 36 \mathrm{~W}$.

Corporation Observatory, Harrogate, March 24.

G. PAUL.

THE sun pillar described by your correspondents was very well seen from the railway between Netley $(5.40)$ and Southampton (6 p.m.), and lasted, I think, more than half an hour. It was visible before and after sunset. The upper air at the time was remarkably calm; the morning had been foggy, and the morning of March 7 was also foggy on the ground. Observation of the upper clouds on the morning of the 6th, and at the time of the phenomenon, showed an extremely slow movement from the north-west, barely noticeable between telegraph wires overhead. At $9 \mathrm{a} . \mathrm{m}$. on the 7 th cirrus was moving very slowly from about north, and at noon from north-west.

R. RUSSELL

Condercum, Alum Chine, Bournemouth, March 24.

THE accounts of this rather rare phenomenon (as it seems to be) come (so far) only from the south-west of England. It is, therefore, worth while adding the following as seen at Oxford by myself and friends :-

March 6, 6.I8 p.m.-A vertical pillar of flame-coloured light, springing probably from the sun below the horizon, quite parallel.sided, about $\frac{2}{3}^{\circ}$ wide and $6^{\circ}$ high, careful measurements, perfectly steady for the Io minutes that we were able to look that way. We thought there was a condensation of light, as of a faint mock sun, about $4^{\circ}$ above the horizon. It was fading off downwards appreciably at the last moment.

Littlemore, Oxford.

W. J. Herschel.

IF the phenomenon of so-called "sun pillars" can only obtain when the atmosphere is "quite free from convection currents . . . (which it seldom is) "[see Nature, March 2o], is it not reasonable to suspect that the thing seen on March 6 was not such an atmospherical phenomenon? since it was viewed east and west from Brighton to the Cornish coast and northwards to High Barnet and Carmarthen Bay, so far as has been already ascertained.

If the barometrical and thermometrical readings, wind velocities and directions over this wide area on the 5th, 6 th and 7 th inst. could be obtained, an examination of these would go far to settle the question.

Bradfield, Berks, March $3 \mathrm{I}$.

\section{Sounds Associated with Low Temperatures.}

THE whistling or squeaking of snow under foot at low temperatures is a familiar phenomenon to residents in such climates as that of Canada. The sound is in strong contrast to the crunching of snow at the freezing point.

I suspect that "walking about the sheds" in the letter quoted by Sir Wm. Preece (p. 487) means walking over snowcovered ground between the sheds.

I I Leopold Road, Ealing, March 29.

I HAVE, I think, frequently heard the sounds mentioned in the letter sent to you by Sir William Preece; but if the sounds I mean are the same as those there described they are not necessarily associated with low temperatures, though they would be more likely to be noticed when the ground is frozen. The sounds to which I refer are to be heard near palings or sheds made, as they frequently are, with overlapping boards. The explanation I have always supposed to be as follows:- If the ground is sharply. struck, with the boot for instance, the sound thus made will be reflected back by the ends of the boards; as each of these ends is further from the listener than its neighbour, the echoes will come back at intervals depending on the distance of the observer from the paling and on the width of the boards ; if the boards are of equal width, the echoes will come back with nearly equal intervals between them, thus producing a musical note. If the ground is frozen, the sharp sounds necessary will be produced when walking by one's boo

NO. I692, voL. 65$]$ striking the ground; but the same sounds may be produced in dry weather and especially when walking on gravel. I have often observed the musical note, but never where such an explanation would not be possible. Wooden palings are not, however, necessary; I have heard the same thing when walking past iron palings, more particularly, as is to be expected, when the uprights have a square section.

Binsted, Cambridge, March $3 \mathrm{r}$.

\section{CENTRAL AND SOUTH AMERICA. ${ }^{1}$}

CENTRAL AMERICA and the West Indies are C attracting so much attention at present that a comprehensive description of them is of especial value to all who are watching the growth of political power in the New World. Hence we may welcome Mr. Keane's work, which, inter alia, treats of their history, physical geography, climate, flora, fauna, ethnology and industries, as well as of their financial and commercial statistics. The volume, although purporting to be a " new issue," might well claim to have no relation to the old one, edited, a quarter of a century ago, by the well-known naturalist H. W. Bates; for the knowledge of the region which has accumulated during the interval has been largely utilised, although not brought up to date in some important respects. Besides ten carefully executed maps, not overloaded and confused by unimportant names, the work contains numerous illustrations.

Mr. Keane opens his subject with a comprehensive chapter on the physical and biographical relations of the countries under consideration. "The present Central American mainland, like the Southern continent, formed, originally, a vast insular region, which was gradually consolidated in Tertiary and later times. It constituted a great archipelago, which stretched, for about 770 miles, in a south-easterly direction from Tehuantepec to Panama, and presented certain analogies to the West Indian insular world, with which it is in fact connected by at least two chains of islets, reefs, and partly or wholly submerged marine banks. . . . It is difficult to realise the fact that the 'American Mediterranean,' as the Gulf of Mexico and Caribbean Sea are often called, has a circuit from Cape Sable round to the Bahamas of no less than 12,000 miles. . . The volume of water (the Gulf Stream) rejoining the equatorial current north of Florida strait, though relatively small, forms none the less a liquid mass about fifty-five miles wide and 450 fathoms deep moving at the rate of from two to six miles an hour, and is thus equivalent to as many as 300,000 rivers as copious as the Mississippi." It may be remarked that Maury is contented with giving the flow of the Gulf Stream through this strait as Iooo times the volume of the mighty river mentioned.

Mr. Keane discusses at length the ethno-geographical relations of the almost numberless tribes which have made the lands bordering the Gulf of Mexico and Caribbean Sea such an interesting study, and he concedes to the Toltec; Aztec and Maya peoples a high degree of civilisation. Most writers do the same, as they let their imagination revel in the romantic accounts of the conquest of Mexico and the descriptions of the ruins found from New Mexico to Panama; but it may be doubted if any of the tribes of Indians who occupied that region ever reached a higher grade than the "Upper Status of Barbarism" so admirably defined by Lewis $\mathrm{H}$. Morgan in his "Ancient Society."

As to the Carib race, the cradle of which Mr. Keane rightly fixes in the heart of South America, they wandered north to the shores of the Caribbean Sea, to which they gave their name, and which recognised, throughout its

1 Stanford's " Compendium of Geography and Travel" (new issue). "Central and South America." Vol. ii. Central America and West Indies. By A. H. Keane, F.R.G.S. Edited by Sir Clements Markham, K.C.B., F.R.S. Pp. xxiv 496. (London: E. Stanford.) Price $15^{s}$. 